\title{
Review Article \\ Rare Earth Elements: Their Importance in Understanding Soil Genesis
}

\author{
Michael T. Aide and Christine Aide \\ Department of Agriculture, Southeast Missouri State University, 1 University Plaza, Cape Girardeau, MO 63701, USA \\ Correspondence should be addressed to Michael T. Aide, mtaide@semo.edu
}

Received 5 January 2012; Accepted 23 February 2012

Academic Editors: G. Benckiser, L. Mercury, and W. Peijnenburg

Copyright (๑) 2012 M. T. Aide and C. Aide. This is an open access article distributed under the Creative Commons Attribution License, which permits unrestricted use, distribution, and reproduction in any medium, provided the original work is properly cited.

The rare earth elements (REEs) are commonly defined as lanthanum (La) and the 14 elements comprising the Lanthanide series. The REE's typically exhibit trivalent oxidation states; however, Europium may also occur as $\mathrm{Eu}^{2+}$ and Cerium may occur as Ce ${ }^{4+}$. The REE's ionic radii decrease on progression from La to Lu, which results in a slight but predictable change in their chemical affinity. Typically, the light REE (La to Sm) reside in trace minerals such as apatite, epidote and allanite, whereas the heavy REE (Gd to $\mathrm{Lu}$ ) are associated with minerals such as zircon. Investigations typically show that the REE are depleted in near-surface horizons and accumulate in deeper horizons or the regolith as clay-oxyhydroxide adsorbates or REE-phosphate precipitates. Numerous studies show the heavy REE accumulating in the deeper soil regions to a greater extent than the light REE, whereas other studies show the light REE's preferentially accumulating at greater soil depths. The degree of interhorizon transport has great potential to become an index of weather intensity. The various REE soil migration pathways have been isolated, including lessivage, soil organic matter complexation, leaching in percolating water, adsorption by inorganic colloids, and precipitated by phosphatebearing minerals.

\section{The Inorganic Chemistry of the Rare Earth Elements}

The rare earth elements (REEs) are commonly defined as lanthanum (La) and the 14 elements comprising the Lanthanide series: cerium (Ce), praseodymium $(\mathrm{Pr})$, neodymium $(\mathrm{Nd})$, promethium $(\mathrm{Pm})$, samarium $(\mathrm{Sm})$, europium $(\mathrm{Eu})$, gadolinium $(\mathrm{Gd})$, terbium $(\mathrm{Tb})$, dysprosium (Dy), holmium (Ho), erbium (Er), thulium ( $\mathrm{Tm})$ ytterbium $(\mathrm{Yb})$, and lutetium $(\mathrm{Lu})$. The Lanthanide series consists of unique elements characterized as having a ground state electronic configurations having at least one electron in the $4 \mathrm{f}$ electronic orbital. Yttrium (Y) is frequently included as a rare earth element because of its small ionic radius, approximately the same ionic radius as Ho. Lanthanum is frequently associated because of its position in the Periodic Table and its similar trivalent chemical affinity. The symbol $\mathrm{Ln}^{3+}$ is frequently used as a generic representation for the rare earth elements having trivalent cationic form. Promethium undergoes radioactive decay (half-life is 2.62 years) and its presence in the natural environment is virtually nonexistent [1].
The uniqueness and importance of the REEs stem from their chemical similarity attributed to the predominance of trivalent REEs species forming an array of minerals [1]. Although the lanthanide series is defined as elements having partially to completely filled 4 f-orbital ground-state electronic configurations (Table 1), the $\mathrm{Ln}^{3+}$ species result from having three electrons removed from their $\mathrm{d}, \mathrm{s}$, and $\mathrm{f}$ orbitals. The number of $f$ orbital electrons remaining in each $\mathrm{Ln}^{3+}$ species corresponds with their order in the Lanthanide series (La has no $f$ orbital electrons, Ce has one $f$ orbital electron, Pr has two f orbital electrons, to Lu having $14 \mathrm{f}$ orbital electrons). The REEs display considerable ionic bonding character and are considered hard acids, features attributed to their s, $\mathrm{d}$, and $\mathrm{f}$ orbital interactions [1].

Europium has a ground state electronic configuration ([Xe] $4 \mathrm{f}^{7} 6 \mathrm{~s}^{2}$ ) with a half-filled $\mathrm{f}$ orbital, allowing particular stability for the $\mathrm{Eu}^{2+}$ species. The ionic radius of $\mathrm{Eu}^{2+}$ is very similar to that of strontium ( $\mathrm{Sr})$; therefore, $\mathrm{Eu}^{2+}$ participates in isomorphic substitution with $\mathrm{Sr}^{2+}$ in selected minerals. Similarly, Ce exhibits oxidation-reduction behavior and its electronic ground state configuration ([Xe] $4 \mathrm{f}^{1} 5 \mathrm{~d}^{1} 6 \mathrm{~s}^{2}$ ) 
TABLE 1: Chemical properties of the rare earth elements, including La, Sc, and Y.

\begin{tabular}{|c|c|c|c|c|}
\hline \multirow{2}{*}{ Element } & \multicolumn{2}{|c|}{ Atomic $^{1}$} & \multirow[b]{2}{*}{ Ground state Configuration $^{1}$} & \multirow[b]{2}{*}{ Name } \\
\hline & Number & Weight & & \\
\hline \multicolumn{5}{|c|}{ Trivalent REE } \\
\hline $\mathrm{La}$ & 57 & 138.9055 & {$[\mathrm{Xe}] 5 \mathrm{~d}^{1} 6 \mathrm{~s}^{2}$} & Lanthanum \\
\hline $\mathrm{Ce}$ & 58 & 140.12 & {$[\mathrm{Xe}] 4 \mathrm{f}^{1} 5 \mathrm{~d}^{1} 6 \mathrm{~s}^{2}$} & Cerium \\
\hline $\operatorname{Pr}$ & 59 & 140.9077 & {$[\mathrm{Xe}] 4 \mathrm{f}^{3} 6 \mathrm{~s}^{2}$} & Praseodymium \\
\hline $\mathrm{Nd}$ & 60 & 144.24 & {$[\mathrm{Xe}] 4 \mathrm{f}^{4} 6 \mathrm{~s}^{2}$} & Neodymium \\
\hline $\mathrm{Pm}$ & 61 & 145 & {$[\mathrm{Xe}] 4 \mathrm{f}^{5} 6 \mathrm{~s}^{2}$} & Promethium \\
\hline Sm & 62 & 150.36 & {$[\mathrm{Xe}] 4 \mathrm{f}^{6} 6 \mathrm{~s}^{2}$} & Samarium \\
\hline $\mathrm{Eu}$ & 63 & 151.96 & {$[\mathrm{Xe}] 4 \mathrm{f}^{7} 6 \mathrm{~s}^{2}$} & Europium \\
\hline Gd & 64 & 157.25 & {$[\mathrm{Xe}] 4 \mathrm{f}^{7} 5 \mathrm{~d}^{1} 6 \mathrm{~s}^{2}$} & Gadolinium \\
\hline $\mathrm{Tb}$ & 65 & 158.9254 & {$[\mathrm{Xe}] 4 \mathrm{f}^{9} 6 \mathrm{~s}^{2}$} & Terbium \\
\hline Dy & 66 & 162.50 & {$[\mathrm{Xe}] 4 \mathrm{f}^{10} 6 \mathrm{~s}^{2}$} & Dysprosium \\
\hline Ho & 67 & 164.9304 & {$[\mathrm{Xe}] 4 \mathrm{f}^{11} 6 \mathrm{~s}^{2}$} & Holmium \\
\hline $\mathrm{Er}$ & 68 & 167.26 & {$[\mathrm{Xe}] 4 \mathrm{f}^{12} 6 \mathrm{~s}^{2}$} & Erbium \\
\hline $\operatorname{Tm}$ & 69 & 168.93 & {$[\mathrm{Xe}] 4 \mathrm{f}^{13} 6 \mathrm{~s}^{2}$} & Thulium \\
\hline $\mathrm{Yb}$ & 70 & 173.04 & {$[\mathrm{Xe}] 4 \mathrm{f}^{14} 6 \mathrm{~s}^{2}$} & Ytterbium \\
\hline $\mathrm{Lu}$ & 71 & 174.967 & {$[\mathrm{Xe}] 4 \mathrm{f}^{14} 5 \mathrm{~d}^{1} 6 \mathrm{~s}^{2}$} & Lutetium \\
\hline \multicolumn{5}{|c|}{ Other notable elements } \\
\hline \multicolumn{5}{|l|}{$\mathrm{Eu}^{2+}$} \\
\hline \multicolumn{5}{|l|}{$\mathrm{Ce}^{4+}$} \\
\hline $\mathrm{Sc}^{3+}$ & 21 & 44.9559 & {$[\mathrm{Ar}] 3 \mathrm{~d}^{1} 4 \mathrm{~s}^{2}$} & Scandium \\
\hline $\mathrm{Y}^{3+}$ & 39 & 88.9059 & {$[\mathrm{Kr}] 4 \mathrm{~d}^{1} 5 \mathrm{~s}^{2}$} & Yttrium \\
\hline $\mathrm{Ca}^{2+}$ & 20 & 40.078 & {$[\mathrm{Ar}] 4 \mathrm{~s}^{2}$} & Calcium \\
\hline $\mathrm{Mn}^{2+}$ & 25 & 54.938 & {$[\mathrm{Ar}] 3 \mathrm{~d}^{5} 4 \mathrm{~s}^{2}$} & Manganese \\
\hline $\mathrm{Sr}^{2+}$ & 38 & 87.62 & {$[\mathrm{Kr}] 5 \mathrm{~s}^{2}$} & Strontium \\
\hline $\mathrm{Th}^{4+}$ & 90 & 232.0381 & {$[\mathrm{Rn}] 6 \mathrm{~d}^{2} 7 \mathrm{~s}^{2}$} & Thorium \\
\hline $\mathrm{U}^{4+}$ & 92 & 238.0289 & {$[\mathrm{Rn}] 5 \mathrm{f}^{3} 6 \mathrm{~d} 7 \mathrm{~s}^{2}$} & Uranium \\
\hline
\end{tabular}

${ }^{1}$ :see [1].

permits either $\mathrm{Ce}^{3+}$ or $\mathrm{Ce}^{4+}$, with electron configurations corresponding to $[\mathrm{Xe}] 4 \mathrm{f}^{1}$ and $[\mathrm{Xe}]$, respectively.

The influence of $\mathrm{f}$ orbitals on the chemical attributes of the REEs is readily apparent by observing the regular decrease in the ionic radii on progression from $\mathrm{La}$ to $\mathrm{Lu}$ (Table 1). The so-called "Lanthanide Contraction" arises because of the incomplete electric field shielding by the $f$ orbitals and unit increases in nuclear charge on transition to greater atomic numbers. The importance of the lanthanide contraction phenomena is revealed in the greater chemical affinity for hydrolysis and greater stability of selected complexes on progression from the LREEs to the HREEs. LREEs are the light rare earth elements, comprised of the elements $\mathrm{La}$ to $\mathrm{Eu}$, whereas HREEs are the heavy rare earth elements, comprised of the elements Gd to Lu.

The ionic radius of any cationic species is experimentally determined and is largely dependent on its atomic number, oxidation state, the coordination number $(\mathrm{CN})$, and the radius of the anionic species. The ionic radii of REEs having octahedral coordination (CN 6) ranges from $103.2 \mathrm{pm}$ for $\mathrm{La}$ to $86.1 \mathrm{pm}$ for $\mathrm{Lu}\left(\mathrm{pm}=\right.$ picometer $=10^{-12}$ meters $)$, whereas the ionic radii of the REEs having cubic coordination (CN 8) ranges from $116.0 \mathrm{pm}$ for La to $97.7 \mathrm{pm}$ for $\mathrm{Lu}$. The ionic radii for $\mathrm{Ln}^{3+}$ species are generally smaller than the ionic radii for $\mathrm{K}^{+}, \mathrm{Rb}^{+}, \mathrm{Cs}^{+}$, and $\mathrm{Ba}^{2+}$, whereas $\mathrm{Mn}^{2+}, \mathrm{Y}^{3+}, \mathrm{Th}^{4+}$, and $\mathrm{U}^{4+}$ have smaller ionic radii than $\operatorname{Ln}^{3+}[1,2]$. The ionic radius of $\mathrm{O}^{2-}$ is $140 \mathrm{pm}$ and corresponding octahedral $(\mathrm{CN}$ $6)$ and cubic ( $\mathrm{CN} \mathrm{8)}$ cavities accommodate ionic radii from 58 to $102.5 \mathrm{pm}$ and greater than $102.5 \mathrm{pm}$, respectively.

\section{Rare Earth Element Rock and Sediment Abundances}

Chondrite meteorites are generally considered to be composed of igneous materials that have not had an extensive history of melting and recrystallization, thus the REEs composition is considered to be representative of magma prior to any fractionation processes. Historically, igneous petrologists have used chondrite REEs concentrations to index or "normalize" rock samples (REEs ratio of the sample/chondrite) to estimate the type and extent of magmatic processes responsible for lithosphere evolution.

Rock REEs concentrations vary markedly with rock type and source area. In general, most parent materials have REEs compositions ranging from 0.1 to $100 \mathrm{mg} / \mathrm{kg}$, thus the REEs actually have moderate concentration ranges compared with many other trace elements. Rhyolites and granites typically have greater REEs concentrations than basalts and peridotites (Figure 1), with the LREEs concentrations 


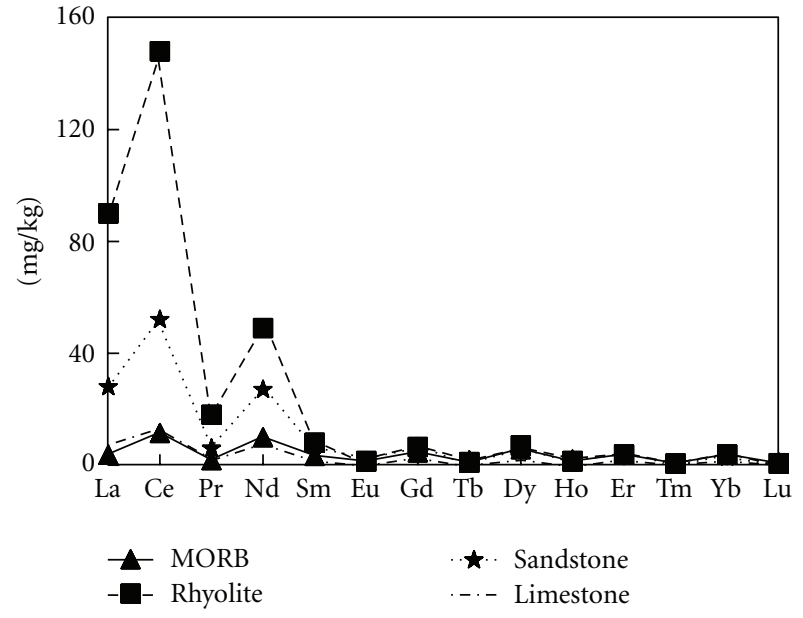

FIGURE 1: REEs concentration values for an average rhyolite, midocean ridge basalt, sandstone and limestone. Concentration values were reported in Kabata-Pendias [4].

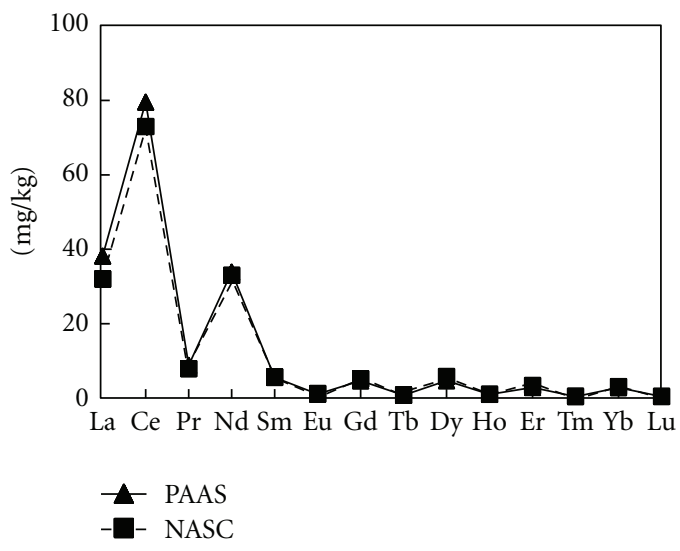

FIgURE 2: REEs concentration values for Post-Archean Australian Average Shale (PAAS) and North American Shale Composite (NASC). Concentration values were reported in McLennan et al. [5] with original citations in Taylor et al. [6] for the PAAS and original citations in Gromet et al. [7] for the NASC.

markedly greater than the HREEs concentrations. Rare earth element concentrations have been routinely determined using instrumental neutron activation analysis [3].

Argillaceous sediments and shales typically have greater REEs concentrations than limestones and sandstones (Figure 1). As with igneous materials, sedimentary materials typically exhibit greater LREEs concentrations than HREEs concentrations.

Important reference standards for sediments include the Post-Archean Australian Shale (PAAS) and the North American Shale Composite (NASC) (Figure 2). The LREEs typically exhibit greater abundances than the HREEs.

Loess is a Pleistocene-Holocene aged silty-textured sediment deposited by wind from major river valleys, primarily in North America, Europe-Russia and China. Typical loess REEs distributions were reported by Kabata-Pendias [4], showing that the LREEs concentrations were greater than those of the HREEs (Figure 3). Also included in Figure 3 is

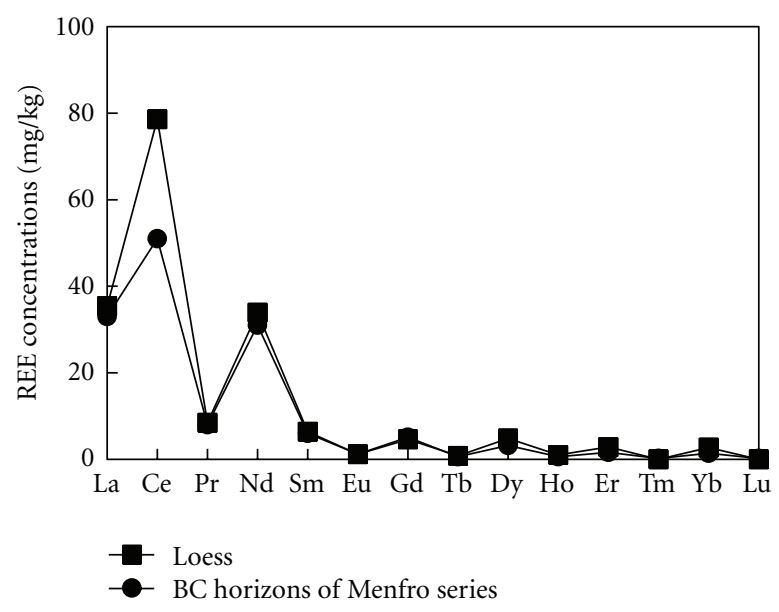

FIGURE 3: REEs concentration values for a typical loess. Loess REEs concentration values were reported in Kabata-Pendias [4], whereas the REE concentrations from two soils of the Menfro (Missouri) series are unpublished data by the author.

the REEs distribution of the average of two $\mathrm{BC}$ horizons from pedons of the Menfro series (Typic Hapludalfs) located in deep Peoria Loess along the Mississippi River in Missouri. The minerals apatite and zircon are frequently the dominant REEs-bearing trace minerals in soils, thus their REEs contribution may substantially influence the whole soil REEs concentrations [2].

The Oddon-Harkins rule states that an element with an even atomic number has a greater abundance than the next element in the Periodic Table. The REEs frequently obey the Oddon-Harkin rule; such that, Ce (atomic number = 58) typically has a greater concentration than $\operatorname{Pr}(59)$ and culminating with $\mathrm{Yb}(70)$ having a greater concentration than $\mathrm{Lu}$ (71). Observation of the Chondrite, PAAS, NASC, and other parent material elemental compositions reflect the Oddon-Harkin rule.

\section{Rare Earth Element Abundances in Primary Minerals}

Primary minerals are minerals formed at the time of rock formation and have not been chemically altered by supergene or weathering processes. REE compositions of primary minerals show dramatic element abundance differences and many primary minerals show enrichment or depletion of selected REEs or groupings of the REEs. The mineral apatite is generally enriched in the LREEs and the mineral zircon is generally enriched in the HREEs. Zircon is commonly considered highly resistant to weathering, thus a large portion of the HREE pool may reside in zircon lattice positions and are not amenable to interhorizon transport. Table 2 lists unpublished instrumental neutron activation analysis of microcline, oligoclase, hornblende, and augite to illustrate selected REE concentrations.

A brief listing of some common REE-bearing minerals, showing REE lattice substitution, are in Table 3. 
TABLE 2: Instrumental neutron activation analysis of selected REEs in selected minerals.

\begin{tabular}{|c|c|c|c|c|c|c|c|c|}
\hline Mineral & $\mathrm{La}$ & $\mathrm{Ce}$ & $\mathrm{Nd}$ & $\mathrm{Sm}$ & $\mathrm{Eu}$ & $\mathrm{Tb}$ & $\mathrm{Yb}$ & $\mathrm{Lu}$ \\
\hline & \multicolumn{8}{|c|}{$\mathrm{mg} / \mathrm{kg}$} \\
\hline Microcline & bdl & 20 & 23 & bdl & 0.2 & bdl & bdl & bdl \\
\hline Oligoclase & bdl & 27 & 49 & bdl & 1.7 & 1.1 & 0.6 & 0.17 \\
\hline Hornblend & 5 & 7 & 31 & 3.2 & 0.7 & bdl & 1.2 & 0.05 \\
\hline Augite & 36 & 39 & 57 & 4.4 & 0.4 & 1.3 & 5.1 & 1.25 \\
\hline Detection limit & 1 & 3 & 10 & 0.5 & 0.2 & 0.5 & 0.5 & 0.05 \\
\hline
\end{tabular}

bdl: below detection limit.

Unpublished analysis by instrumental neutron activation analysis by authors.

TABLE 3: Common minerals having rare earth element (REE) substitution.

\begin{tabular}{lll}
\hline Mineral & Formula & Comments \\
\hline Fluorite & $\mathrm{CaF} 2$ & $\mathrm{Y}$ and Ce replace Ca \\
Allanite & $(\mathrm{Ce}, \mathrm{Ca}, \mathrm{Y})_{2}\left(\mathrm{Al}, \mathrm{Fe}^{2+}, \mathrm{Fe}^{3+}\right)_{3}\left(\mathrm{SO}_{4}\right)_{3} \mathrm{OH}$ & $\mathrm{Y}$ and REE replace Ca \\
Sphene & $\mathrm{CaTiSiO}^{5}$ & $\mathrm{Y}$ and HREE replace $\mathrm{Zr}$ \\
Zircon & $\mathrm{ZrSiO}_{4}$ & $\mathrm{Y}$ and REE replace Ca \\
Apatite & $\mathrm{A}_{5}\left(\mathrm{XO}_{4}\right)_{3}(\mathrm{~F}, \mathrm{OH}, \mathrm{Cl}) ; \mathrm{A}=\mathrm{Ca}, \mathrm{Be}, \mathrm{Ce}, \mathrm{Pb}$ & \\
Monazite & $(\mathrm{CeLa}) \mathrm{PO}_{4}$ & REE replaces Y \\
Xenotime & $\mathrm{YPO}_{4}$ & REE replaces La \\
Rhabdophane & $(\mathrm{Ce}, \mathrm{La}) \mathrm{PO} 4$ & $\mathrm{La}(\mathrm{REE})$-fluorocarbonate \\
Bastnaesite & &
\end{tabular}

Reported in Clark [8].

\section{Rare Earth Element Abundances in Secondary Minerals}

Secondary minerals are minerals formed in the near surface environment by precipitation reactions and incongruent or congruent weathering reactions. In some cases, REEs are involved with isomorphic substitution or undergo adsorption reactions with phyllosilicates or oxyhydroxides. REEphyllosilicate interactions have been investigated, with the majority of studies reporting that the REE elements form weak outer-sphere complexes (exchangeable) at $\mathrm{pH}$ levels in acidic environments and an increasing degree of inner sphere complexes at $\mathrm{pH}$ levels approaching 5 and transitioning to more alkaline soil environments [9-17] in selected alluvial Albaqualfs in Missouri accumulated $\mathrm{Ce}$ and revealed a positive Ce anomaly, suggesting that alternating conditions of oxidation-reduction were important for Fe-Mn nodule synthesis and Ce incorporation.

Kronberg et al. [18] investigated Amazon deep-sea fan deposits and inferred that intense chemical weathering and erosion in adjacent mountainous regions were responsible for the large REE sediment concentrations. Condie [19] and Nesbitt and Markovics [20] previously proposed that the continental weathering and fluvial systems operate to accumulate REE in depositional basins.

Precipitation reactions with fluoride, phosphate, and carbonate may yield a variety of secondary REE minerals [8]. Cerianite $\left(\mathrm{CeO}_{2}\right)$ may form in oxidizing soil solutions [2127]. [8] have documented an impressive listing of primary and secondary minerals having REE incorporation.

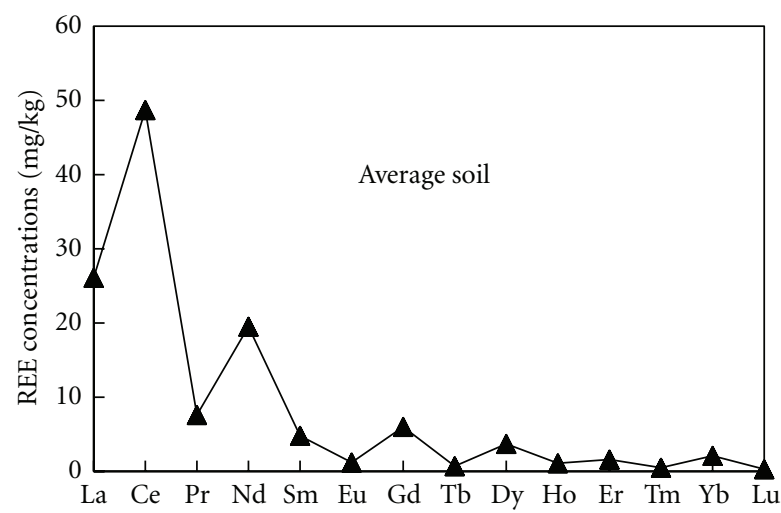

FIGURE 4: REE concentration values for an average soil. Concentration values were reported in Kabata-Pendias [4].

\section{Rare Earth Element Abundances in Soil}

Rare earth element abundances in soils are influenced by their parent materials, texture, weathering history and pedogenic processes, organic matter contents and reactivity, and anthopogenic disturbances. In a review of trace element occurrences, Kabata-Pendias [4] complied mean REE concentrations of selected parent materials and surface horizons of soils. For soils, the LREE concentrations are generally greater than the HREE concentrations and the REE concentration distribution typically obey the Oddon-Harkin rule (Figure 4). 


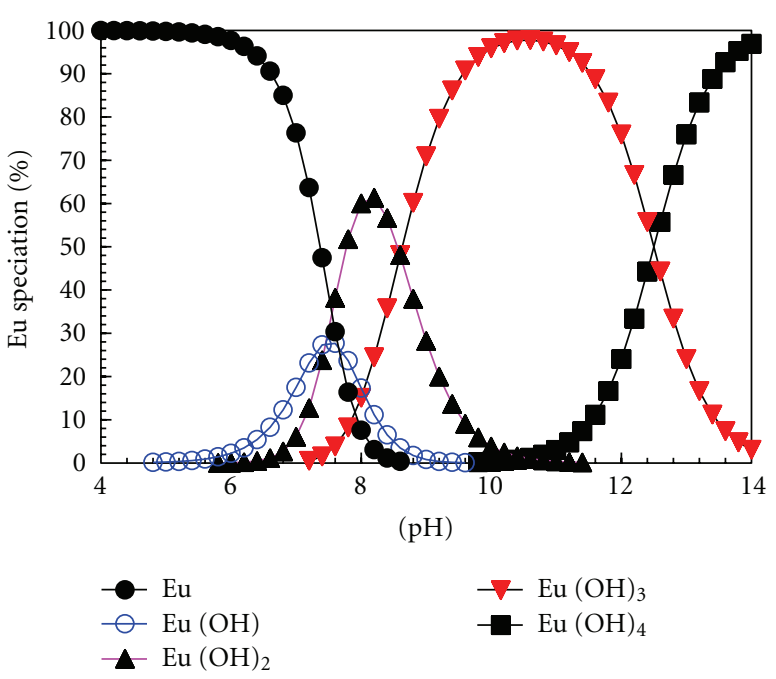

Figure 5: Aqueous hydroxyl speciation of Eu (III) over a pH interval. The Eu speciation involved concentrations without recourse to activity coefficients and overall formation quotients from Baes and Mesmer [28].

The REE concentrations in the soil environment are essentially the weighted mean of the REE concentrations of the minerals in the soil and the associated REE-bearing mineral abundances. In most soil cases, the whole soil REE concen-trations are more directly related to the presence of a few trace minerals, such as apatite and zircon. REE associations with soil organic matter, phosphate precipitates, phyllosilicate and oxyhydroxides may be important in discerning REE soil migration and availability; however, the REEs in youthful soils having little weathering of the REE-bearing minerals usually reveal little REEs mobility.

\section{REE Chemistry and Soil Pedogenic Processes}

The hydrolysis of $\mathrm{Ln}^{3+}$ species has been extensively investigated and numerous authors have published hydrolysis data $[16,17,28-32]$. For example, $\mathrm{Eu}^{3+}$ will undergo hydrolysis to produce $\mathrm{Eu}(\mathrm{OH})^{2+}, \mathrm{Eu}(\mathrm{OH})_{2}{ }^{+}, \mathrm{Eu}(\mathrm{OH})_{3}$ and $\mathrm{Eu}(\mathrm{OH})_{4}{ }^{-}$, having $\log \mathrm{K}^{\circ}$ constants $\log \mathrm{K}_{11}{ }^{\circ}=-7.64, \log \mathrm{K}_{12}{ }^{\circ}=-15.1$, $\log \mathrm{K}_{13}{ }^{\circ}=-23.7$, and $\log \mathrm{K}_{14}{ }^{\circ}=-36.2$, respectively [32]. Europium hydrolysis speciation as a function of $\mathrm{pH}$ illustrates that the $\mathrm{Eu}^{3+}$ species is the dominant species in acidic and near-neutral $\mathrm{pH}$ environments, whereas the $\mathrm{Eu}(\mathrm{OH})_{2}{ }^{+}$, $\mathrm{Eu}(\mathrm{OH})_{3}$, and $\mathrm{Eu}(\mathrm{OH})_{4}{ }^{-}$species are the dominant $\mathrm{Eu}$ species in alkaline and strongly alkaline $\mathrm{pH}$ environments (Figure 5). The hydrolysis speciation of any $\mathrm{Ln}^{3+}$ species is similar to that of $\mathrm{Eu}^{3+}$, with a necessary understanding that the relative stabilities of the various REE hydrolytic species are more stable on transition with increasing atomic number across the Lanthanide series (Figure 6).

Complexation of the REE elements involves coordination with primarily anionic species and typically is expressed as:

$$
\mathrm{Ln}^{3+}+y \mathrm{~L}^{n-}=\operatorname{LnL}_{\mathrm{y}}{ }^{(3-y n)},
$$

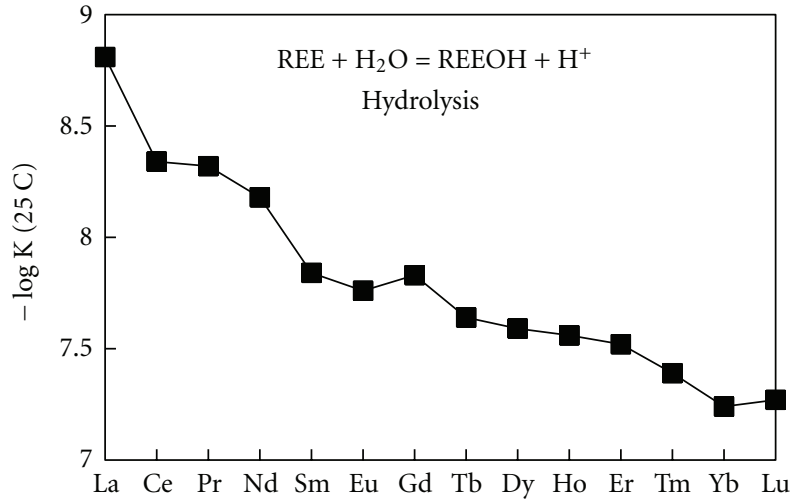

FIgURE 6: REE hydrolysis constants (Values reported in [30]).

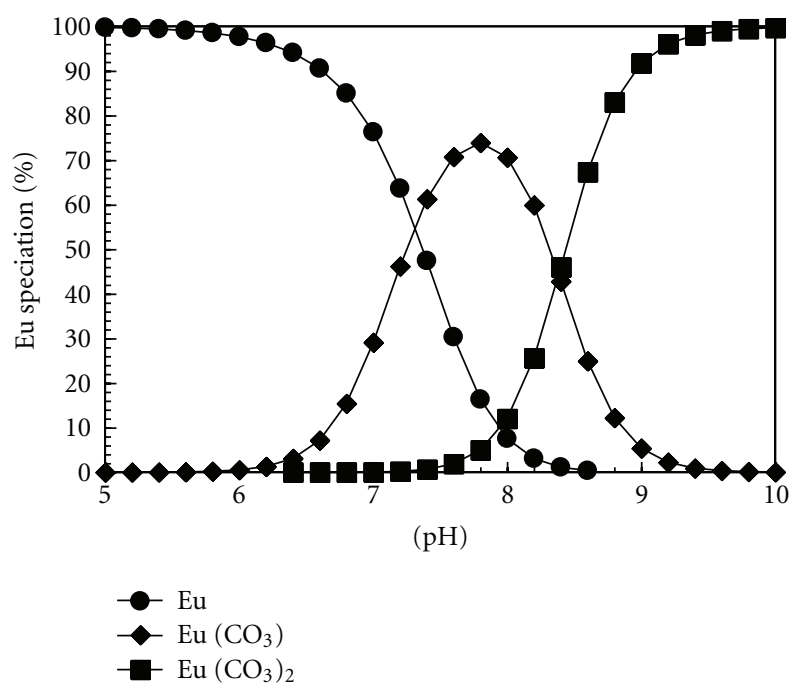

FIgure 7: Aqueous hydroxyl and carbonate speciation of Eu (III). The Eu speciation involved concentrations without recourse to activity coefficients and overall formation quotients from Baes and Mesmer [28], carbonate complexation constants from Luo and Byrne [36], and acid dissociation constants for carbonic acid and bicarbonate from Essington [37]. Author performed calculations using MinteqA2 [38].

where $\mathrm{L}^{n-}$ is an inorganic ligand with $n$ ionic charge and $y$ is the stoichiometric coefficient. Common inorganic complexing species with $\mathrm{Ln}^{3+}$ include $\mathrm{NO}_{3}^{-}, \mathrm{Cl}^{-}, \mathrm{F}^{-}, \mathrm{SO}_{4}^{2-}$, $\mathrm{CO}_{3}^{2-}$, and $\mathrm{HPO}_{4}^{2-}$. Carbonate and dicarbonate complexes exist, with carbonate complexes more prevalent in the LREEs and dicarbonate complexes more prevalent in the HREEs $[16,29,33,34]$ Luo and Byrne, 2000 [35]. For illustration purposes, the Eu speciation involving aqueous equilibrium carbonate complexes with atmospheric $\mathrm{CO}_{2}$ concentrations are displayed in Figure 7.

The complex constants for the formation of $\mathrm{REE}\left(\mathrm{HCO}_{3}\right)^{2+}$ and $\mathrm{REE}\left(\mathrm{HCO}_{3}\right)_{2}^{+}$are displayed in Figure 8. The complexation constants show increasing stability on progression from $\mathrm{La}$ to $\mathrm{Lu}$, with $\mathrm{Gd}$ and $\mathrm{Nd}$ showing slight trend departures. 


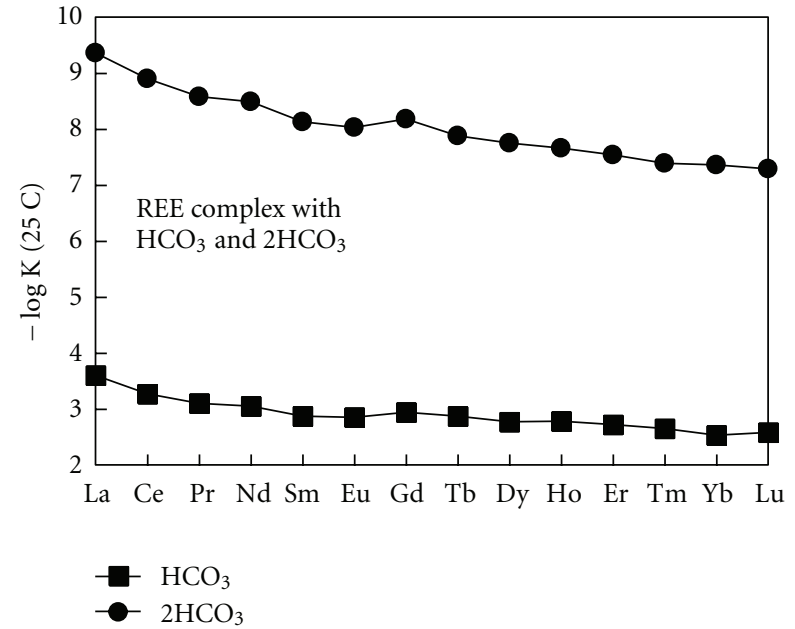

Figure 8: REE complex constants for $\mathrm{HCO} 3$ and $2 \mathrm{HCO} 3$ (values reported in [36]).

Millero [29] and Gramaccioli et al. [39] observed that REE-fluoride complexes obtained greater stability on transition from La to Lu. Banfield and Eggleton [40] emphasized the importance of REE-phosphate precipitates in limiting the mobility of the REE in soils and sediments. Cetiner et al. [41] detailed the REE solubility when phosphate was the determining anion.

Organic acids have been implicated as major weathering agents and organic acid complexation may be a major pathway for interhorizon REE transport $[42,43]$. Common organic complexes involving the REE include both lower molecular weight organic acids and naturally occurring higher molecular weight fulvic and humic acids [20, 24, 4453] Lead et al. [54]. Tyler and Olsson [55] reported that 46 to $74 \%$ of the REE extracted from the aqueous phase of a Swedish Cambisol were associated with dissolved organic carbon. As with the inorganic REE complexes, organic REE complexes tend to show greater stability for the HREEs than the LREEs [33, 51]; however, Ohlander et al. [56] and also Land et al. [47] reported greater stability for the LREEs than the HREEs.

Cao et al. [57] and Tyler and Olsson [58] observed that the strength of REE-organic complex bond strengths are greater with increasing soil $\mathrm{pH}$. Nikonov et al. [59], Dupre et al. [60] and $\mathrm{Gu}$ et al. [49] each proposed that immobile soil organic matter fractions have a range of complexing bond strengths that limit REE mobility. Rare earth element uptake by plant roots has been documented ([61-64]).

Aide (unpublished research) employed a $45 \mathrm{~m} \mu$ filtered water leach extraction on a series of Endoaqualfs (poorly drained Alfisols) and Eutrochepts (somewhat poorlydrained Inceptisols) in southeastern Missouri to show REEs availability (Figure 9). Cerium was consistently the most abundant REE leached from the soils, followed by La and Nd. The LREE had greater leachate concentrations than the HREE. REE compliance with the Oddon-Harkin's rule was consistently observed.

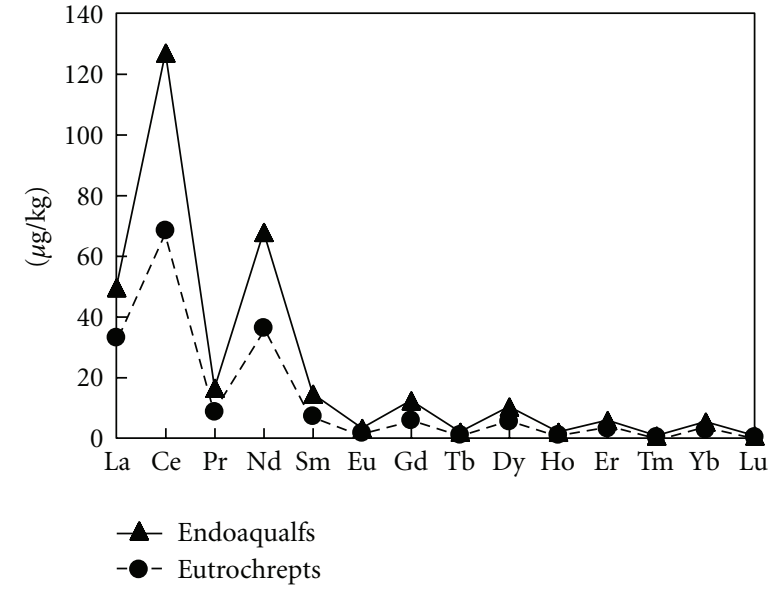

FIGURE 9: Water extraction of REE from Endoaqualfs in Missouri (mean of 27 observations, coefficient of variation is less than five percent) and Eutrochrepts in Missouri (mean of 24 observations, coefficient of variation is less than five percent).

\section{Rare Earth Elements and Soil Development: Case Studies}

The importance of the REEs rests with their "signature," which may be defined as either the actual REE concentrations or their normalized concentrations displayed according to their atomic number. Analysis of the REE signatures typically involves the summation of the total concentrations of all of the REEs ( $\mathrm{REE}$ ) and evidence of fractionation, that is, LREE and HREE ratios, $\mathrm{La} / \mathrm{Yb}$ ratios, $\mathrm{Nd} / \mathrm{Sm}$ ratios, and the presence of $\mathrm{Ce}$ or $\mathrm{Eu}$ anomalies. REE signatures have been compared to reveal (1) lithologic discontinuities [65-67], (2) the presence of aeolian or anthopogenic additions [59, 6870], (3) estimates of the weathering intensities and elemental loss rates of soils $[20,23,24,44,45,47,71-78])$, and (4) oxidation-reduction conditions in soil [79].

REEs in soils were originally assumed to be immobile. Nesbitt [80] in a pioneering study involving soils developed in granodiorite proposed that $\mathrm{CO}_{2}$ and organic matter bearing soil waters percolated through the soil profiles, removing the REEs as carbonate complexes. The REEs were removed from the percolating soil water in deeper, less weathered and less acidic granodiorite materials as exchangeable, adsorbed or precipitated phases. The HREEs were enriched in the deeper material to a greater degree than the LREEs, promoting the concept that the REEs may not act uniformly and that differences in REEs reactivity related to atomic number results in REE segregation (REE fractionation).

Duddy [81] proposed that REEs accumulate in the deeper portions of soils developed from volcanic rocks. Subsequently, Nesbitt and Markovics [20] investigated soil profile development in granodiorite in Australia and showed that the REE and many transition metals and metalloids accumulated in the deeper and less-weathered portions of the soil profiles. They effectively documented that REE leaching and surficial erosion combined to promote the continuous cycling of the REE to deeper soil regions.

Aide et al. [82] investigated a series of Ultisols in southern 


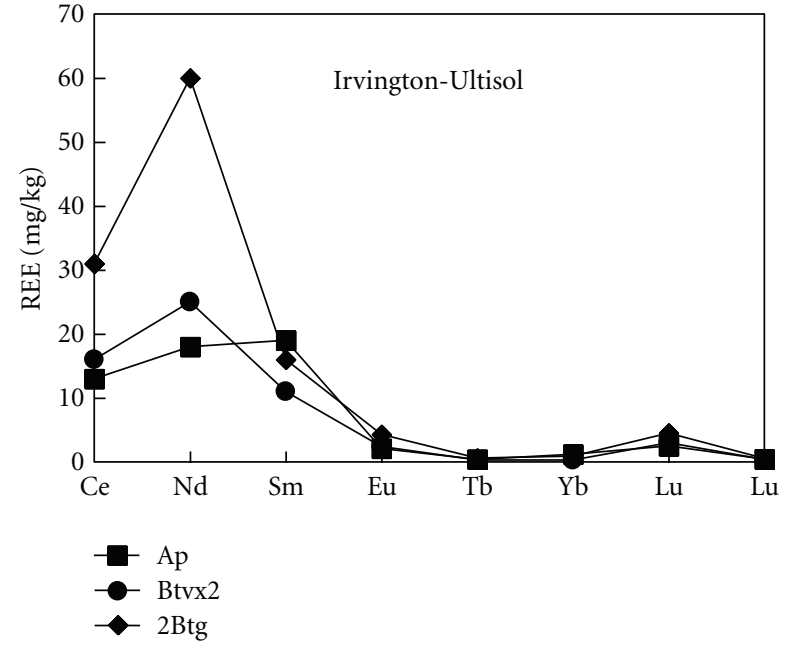

Figure 10: REE concentration values for the Ap, E, and Btvx2 horizons of a soil of the Irvington series.

Mississippi having plinthite (Figure 10). The element Ce has a greater concentration across the lithologic discontinuity indicating either an inherited REE difference or preferential Ce transport across the lithologic discontinuity.

Aide and Smith [83] investigated Paleustoll soils in south central Texas and observed that the LREE concentrations were greater in the argillic horizons than the surface horizons and proposed that the clay fraction in the argillic horizon accumulated the LREEs. In a similar study, Aide et al. [70] investigated Lithic Haplustolls in the Chisos Mountain of Texas and observed that the host rock and the fine earth fraction exhibited similar REE distribution patterns (Figure 11). In this study, the concentrations of the LREE were greater than the HREE and both the soil and host rock exhibited a negative Eu anomaly, suggesting that the soil REE signatures were inherited from the host rock. Aide et al. [65] in Missouri investigated Typic Paleudalfs developed in loess over volcanic residuum and reported that the greater REE concentration in the near surface horizons were attributed to the thin loess mantle, thus assisting in the recognition of parent material differences. In a companion manuscript, Aide et al. [66] used Ti as an immobile index to indicate that the REE have been partially depleted from the soil profiles relative to the host rock.

MacFarlane et al. [73] investigated paleosols in western Australia developed on contrasting basalt flows. They inferred that REE migration promoted the downward movement of the REE to the middle portion of the paleosols and that the relative movement of the LREE was greater than that for the HREE. Prudencio et al. [44] investigated soil development on alkali basalts in the Lisbon Volcanic Complex in Portugal. REE concentrations were greater in the deeper argillic horizons than the overlying soil horizons and the REE concentrations were appreciably greater in the clay separate. They further proposed that apatite weathering in the near surface acidic horizons mobilized the REE, with

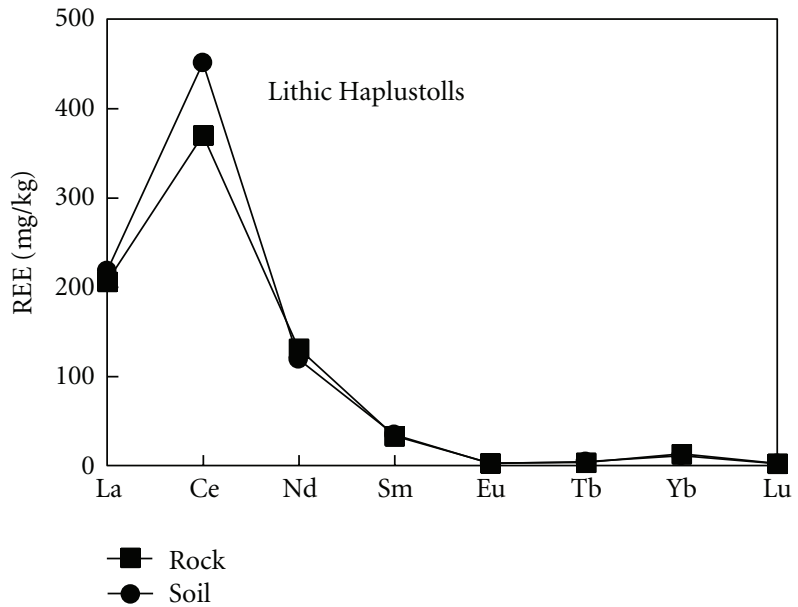

Figure 11: REE concentrations of a Lithic Haplustoll (Brewster series in Texas) showing parent material-soil similarity.

subsequent precipitation of REE-phosphate phases in the deeper soil horizons.

Gouveia et al. [72] investigated the weathering of Portuguese soils developed in granite, resulting in a soil-saprolite-weathering rind-fresh rock sequence. Chondritenormalized REE signatures of the fresh rock indicated a pronounced LREE abundance and a positive Eu anomaly. Compared to the near-surface horizons, the upper portion of the saprolite demonstrated a decreased REE content, whereas the deeper portion of the saprolite showed REE accumulation. The sand fraction showed a low REE concentration attributed to the presence of quartz sand and exhibited a positive Eu anomaly attributed to the presence of plagioclase. The clay fraction demonstrated greater REE concentrations and a negative Eu anomaly, inferring that soil weathering and clay-REE adsorption reactions augmented the clay fraction's REE concentrations.

Aide and Pavich [84] investigated Alfic Haplorthods in northern Wisconsin using instrumental neutron activation analysis for total REE concentrations (Figure 12). An aqua regia digestion procedure recovered nearly as much of the LREE pool as instrumental neutron activation analysis; however, the aqua regia digestion only marginally recovered the HREE pool. Aide and Pavich proposed that apatite was the major repository for the LREE and zircon was the major repository for the HREE. Sodium pyrophosphate extraction of the REE only recovered a small portion of the aqua regia digestion pool, suggesting that that organic fraction was not the dominant REE soil fraction.

REE fractionation was demonstrated in Swedish Spodosols developed in granite till [47]. Land's investigative team documented that the E horizons were REE depleted, when normalized against the granite till, and that REE depletion increased on progression from the LREEs to the HREEs. The Bs horizon was REE depleted, but not to the extent of the overlying E horizon. Selective extractions demonstrated that the crystalline $\mathrm{Fe}$-oxyhydroxide and labile organic fractions accumulated the HREE to a greater extent than the LREE, 


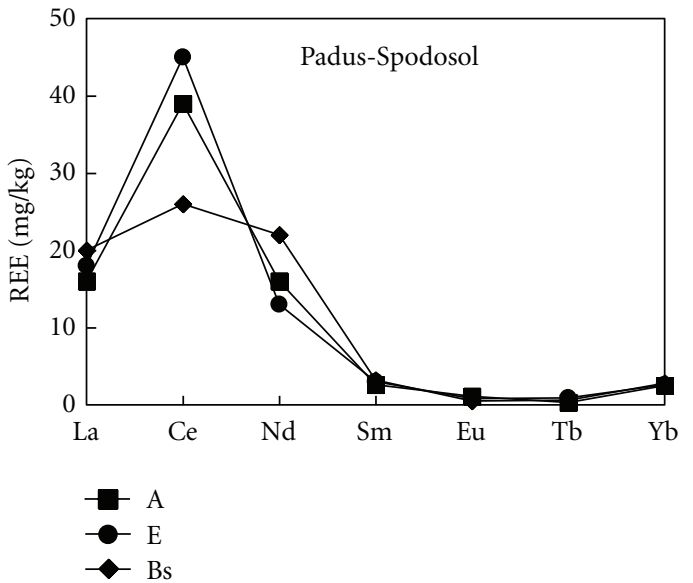

FIGURE 12: REE concentration values for the A, E, and Bs horizons of the soil of the Padus series.

whereas the soil organic matter fraction representing humic and fulvic acids preferentially accumulated the LREE.

In Sweden, Ohlander et al. [56] observed that weathering of a series of Typic Haplocryods developed in till has depleted the REE's in E horizons, with the degree of depletion greater for the LREE. The Bs horizons of these soils showed REE accumulation at some sites, whereas other locations showed REE depletion. They further proposed that hornblende, epidote, apatite, allanite, and monazite release REEs on weathering and that the clay fraction, with its greater oxyhydroxide and adsorbed organic matter content, may be an important adsorptive repository for the REE, thus inhibiting their removal from the soil profile. Tyler and Olsson [58] showed that the majority of the REEs were 40 to $50 \%$ removed from the A and E horizons of a Swedish Haplic Podzol.

Braun and Pagel [45] investigated REE migration in Cameroon lateritic soil profiles developed in Precambrian syenite. The soil profiles generally consisted of four layers: (1) an surface layer consisting of loose, nodular ferruginous materials having indurated hematite nodules, (2) a pedoplinthite (iron crust) layer, (3) a mottled clay layer possessing plinthite, and (4) saprolite with whitish seams of clayey material enclosing the sandy-textured remains of syenite boulders. Analysis of fresh syenite rock revealed that $70 \%$ of the REE pool, $40 \%$ of the HREE pool, and $50 \%$ of the Th pool was contained in allanite, epidote, titanite, and apatite. Thorium was the least mobile element, forming the relatively inert mineral thorianite $\left(\mathrm{ThO}_{2}\right)$. Long-term weathering of these minerals in the Fe-rich upper soil horizons (layers 1 and 2) resulted in REE depletion relative to Th as an indexing element, whereas the deeper clay rich horizons and saprolite showed REE accumulation. The LREE were precipitated as florencite (REE-phosphates), except that $\mathrm{Ce}$ was oxidized and precipitated as cerianite $\left(\mathrm{CeO}_{2}\right)$. The whitish seams demonstrated a positive $\mathrm{Ce}$ anomaly, consistent with cerianite precipitation.

Braun et al. [24] in Cameroon used Th indexing to study REE migration in lateritic soils. The upper horizons,

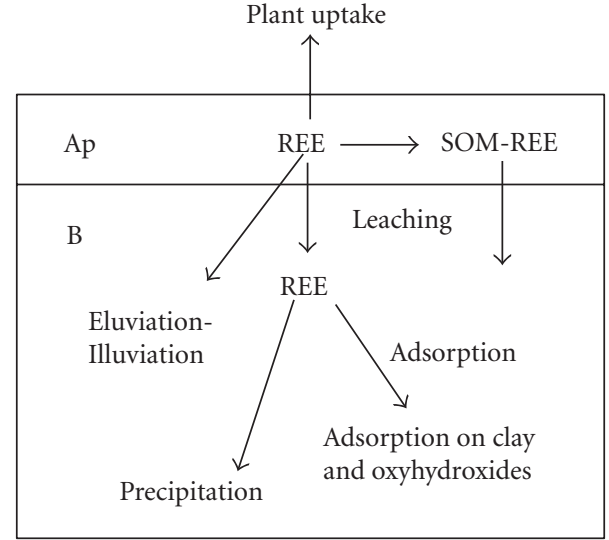

Figure 13: An illustration of the potential pathways for REE migration and sequestration.

consisting of a yellow clayey matric overlying an indurated ferruginous horizon, were REE depleted based on parent rock normalization. The deeper basal saprolite demonstrated zones for the accumulation of Ce and other LREE. The HREE were depleted in the basal saprolite material. The LREE elements were proposed to be precipitated as rhabdophate (LREE- $\left.\mathrm{PO}_{4}-n \mathrm{H}_{2} \mathrm{O}\right)$ and cerianite $\left(\mathrm{CeO}_{2}\right)$. Xenotime was the dominant primary mineral acting as a repository for the HREE. Acidic groundwater extracted from the basal saprolite demonstrated a high LREE content and a negative Ce anomaly, reflecting the REE composition of the parent material. In central Uganda, Brown et al. [77] used Th as an indexing element for highly weathered soils to show REE depletion with little LREE/HREE fractionation.

Oliva et al. [48] studied weathering processes in a small Cameroon watershed containing lateritic landscapes. The majority of the chemical weathering in the watershed was located in basin positions having restricted drainage. The hydromorphic soils exhibited organic-rich over sandytextured horizons which were superimposed on a clayey and mottled section having an abundance of goethite. The deeper clayey layer exhibited an accumulation of LREE and displayed little evidence of a Ce anomaly. The authors proposed that organic acids promoted mineral dissolution and the subsequent transport of $\mathrm{Al}, \mathrm{Fe}, \mathrm{Ti}, \mathrm{Zr}$, and the REEs. The REEs were assumed to have interacted with phosphate to limit their transport and soil profile removal.

\section{Pathways for REE Migration in Soil}

Pathways for REE migration are numerous, involving (1) plant uptake, (2) erosion, (3) leaching of REE-inorganic complexes in percolating water, (4) organic complexation which may result in either mobilization or immobilization of the REEs, (5) lessivage (eluviation-illuviation of clay with coadsorbed REE's, (6) removal of REE's from percolating water attributed to precipitation reactions, and (7) adsorption of REE's by inorganic colloids (phyllosilicates and oxyhydroxides) (Figure 13). An important aspect of the REE's is their similar soil chemistry; however, small differences in their 
hydrolysis and inorganic-organic complexation constants and inherent differences in the weathering susceptibility of the various REE-bearing minerals allow fractionation and differential migration potential. The real value of the REE's to soil scientists lies in their ability to shed light on rates of elemental depletion and soil weathering intensities. If a greater understanding of the REE's result in quantification of soil processes; such as eluviation-illuviation, spodic horizon formation, erosion, elemental depletion because of leaching, oxyhydroxide formation, and haploidization.

\section{References}

[1] N. N. Greenwood and A. Earnshaw, Chemistry of the Elements, Pergamon Press, New York, NY, USA, 2nd edition, 1984.

[2] P. Henderson, "General geochemical properties and abundances of the rare earth elements," in Rare Earth Element Geochemistry, P. Henderson, Ed., pp. 1-29, Elsevier Science, New York, NY, USA, November 1983.

[3] P. A. Helmke, "Neutron activation analysis," in Methods of Soil Analysis: Part 3, Chemical Methods, D. L. Sparks, Ed., pp. 141160, American Society of Agronomy-Soil Science Society of America, Madison, Wis, USA, January 1996.

[4] A. Kabata-Pendias, Trace Elements in Soils and Plants, CRC Press, New York, NY, USA, 3rd edition, 2000.

[5] S. M. McLennan, "Rare earth elements in sedimentary rocks: influence of provenance and sedimentary processes," in Geochemistry and Mineralogy of Rare Earth Elements, B. R. Lipin and G. A. McKay, Eds., vol. 21, Mineralogical Society of Amer, Washington, DC, USA, January 1989.

[6] S. R. Taylor, S. M. McLennan, and M. T. McCulloch, "Geochemistry of loess, continental crustal composition and crustal model ages," Geochimica et Cosmochimica Acta, vol. 47, no. 11, pp. 1897-1905, 1983.

[7] L. P. Gromet, L. A. Haskin, R. L. Korotev, and R. F. Dymek, "The "North American shale composite": its compilation, major and trace element characteristics," Geochimica et Cosmochimica Acta, vol. 48, no. 12, pp. 2469-2482, 1984.

[8] A. M. Clark, "Mineralogy of the rare earth elements," in Rare Earth Element Geochemistry, P. Henderson, Ed., pp. 33-54, Elsevier Science, New York, NY, USA, 1983.

[9] V. A. Sinitsyn, S. U. Aja, D. A. Kulik, and S. A. Wood, "Acidbase surface chemistry and sorption of some lanthanides on $\mathrm{K}^{+}$-saturated, Marblehead illite: I. results of an experimental investigation," Geochimica et Cosmochimica Acta, vol. 64, no. 2, pp. 185-194, 2000.

[10] D. A. Kulik, S. U. Aja, V. A. Sinitsyn, and S. A. Wood, "Acidbase surface chemistry and sorption of some lanthanides on $\mathrm{K}^{+}$, Marblehead illite: II. A multisite-surface complexation modeling," Geochimica et Cosmochimica Acta, vol. 64, no. 2, pp. 195-213, 2000.

[11] M. H. Bradbury and B. Baeyens, "Sorption of Eu on Na- and Ca-montmorillonites: experimental investigations and modelling with cation exchange and surface complexation," Geochimica et Cosmochimica Acta, vol. 66, no. 13, pp. 2325-2334, 2002.

[12] B. Wen, X. Q. Shan, J. M. Lin, G. G. Tang, N. B. Bai, and D. A. Yuan, "Desorption kinetics of yttrium, lanthanum, and cerium from soils," Soil Science Society of America Journal, vol. 66, no. 4, pp. 1198-1206, 2002.

[13] T. Rabung, M. C. Pierret, A. Bauer, H. Geckeis, M. H. Bradbury, and B. Baeyens, "Sorption of $\mathrm{Eu}(\mathrm{III}) / \mathrm{Cm}$ (III) on
Ca-montmorillonite and Na-illite. Part 1: batch sorption and time-resolved laser fluorescence spectroscopy experiments," Geochimica et Cosmochimica Acta, vol. 69, no. 23, pp. 53935402, 2005.

[14] J. Tang and K. H. Johannesson, "Speciation of rare earth ele-ments in natural terrestrial waters: assessing the role of dissolved organic matter from the modeling approach," Geochimica et Cosmochimica Acta, vol. 67, no. 13, pp. 2321-2339, 2003.

[15] M. H. Bradbury, B. Baeyens, H. Geckeis, and T. Rabung, "Sorption of Eu(III)/Cm(III) on Ca-montmorillonite and Naillite. Part 2: surface complexation modelling," Geochimica et Cosmochimica Acta, vol. 69, no. 23, pp. 5403-5412, 2005.

[16] E. Tertre, G. Berger, E. Simoni et al., "Europium retention onto clay minerals from 25 to $150^{\circ} \mathrm{C}$ : experimental measurements, spectroscopic features and sorption modelling," Geochimica et Cosmochimica Acta, vol. 70, no. 18, pp. 4563-4578, 2006.

[17] E. Tertre, A. Hofmann, and G. Berger, "Rare earth element sorption by basaltic rock: experimental data and modeling results using the "generalised composite approach"', Geochimica et Cosmochimica Acta, vol. 72, no. 4, pp. 1043-1056, 2008.

[18] B. I. Kronberg, H. W. Nesbitt, and W. W. Lam, "Upper Pleistocene Amazon deep-sea fan muds reflect intense chemical weathering of their mountainous source lands," Chemical Geo$\log y$, vol. 54, no. 3-4, pp. 283-294, 1986.

[19] K. C. Condie, "Another look at rare earth elements in shales," Geochimica et Cosmochimica Acta, vol. 55, no. 9, pp. 25272531, 1991.

[20] H. W. Nesbitt and G. Markovics, "Weathering of granodioritic crust, long-term storage of elements in weathering profiles, and petrogenesis of siliciclastic sediments," Geochimica et Cosmochimica Acta, vol. 61, no. 8, pp. 1653-1670, 1997.

[21] M. Bau, "Scavenging of dissolved yttrium and rare earths by precipitating iron oxyhydroxide: experimental evidence for Ce oxidation, Y-Ho fractionation, and lanthanide tetrad effect," Geochimica et Cosmochimica Acta, vol. 63, no. 1, pp. 67-77, 1999.

[22] E. H. De Carlo and G. M. McMurtry, "Rare-earth element geochemistry of ferromanganese crusts from the Hawaiian Archipelago, central Pacific," Chemical Geology, vol. 95, no. 3-4, pp. 235-250, 1992.

[23] J. J. Braun, M. Pagel, A. Herbilln, and C. Rosin, "Mobilization and redistribution of REEs and thorium in a syenitic lateritic profile: a mass balance study," Geochimica et Cosmochimica Acta, vol. 57, no. 18, pp. 4419-4434, 1993.

[24] J. J. Braun, J. Viers, B. Dupré, M. Polve, J. Ndam, and J. P. Muller, "Solid/liquid REE fractionation in the lateritic system of Goyoum, East Cameroon: the implication for the present dynamics of the soil covers of the humid tropical regions," Geochimica et Cosmochimica Acta, vol. 62, no. 2, pp. 273-299, 1998.

[25] D. Koeppenkastrop and E. H. De Carlo, "Sorption of rareearth elements from seawater onto synthetic mineral particles: an experimental approach," Chemical Geology, vol. 95, no. 3-4, pp. 251-263, 1992.

[26] J.S. Marsh, "REE fractionation and Ce anomalies in weathered Karoo dolerite," Chemical Geology, vol. 90, no. 3-4, pp. 189194, 1991.

[27] A. Ohta and I. Kawabe, "REE(III) adsorption onto Mn dioxide $\left(\delta\right.$ - $\left.\mathrm{MnO}_{2}\right)$ and Fe oxyhydroxide: $\mathrm{Ce}(\mathrm{III})$ oxidation by $\delta$ $\mathrm{MnO}_{2}$," Geochimica et Cosmochimica Acta, vol. 65, no. 5, pp. 695-703, 2001.

[28] C. F. Baes and R. E. Mesmer, The Hydrolysis of Cations, John 
Wiley and Sons, New York, NY, USA, 1976.

[29] F. J. Millero, "Stability constants for the formation of rare earth-inorganic complexes as a function of ionic strength," Geochimica et Cosmochimica Acta, vol. 56, no. 8, pp. 31233132, 1992.

[30] G. D. Klungness and R. H. Byrne, "Comparative hydrolysis behavior of the rare earths and yttrium: the influence of temperature and ionic strength," Polyhedron, vol. 19, no. 1, pp. 99$107,2000$.

[31] E. Tertre, G. Berger, S. Castet, M. Loubet, and E. Giffaut, "Experimental sorption of $\mathrm{Ni}^{2+}, \mathrm{Cs}^{+}$and $\mathrm{Ln}^{3+}$ onto a montmorillonite up to $150^{\circ} \mathrm{C}$," Geochimica et Cosmochimica Acta, vol. 69, no. 21, pp. 4937-4948, 2005.

[32] E. Hummel, U. Berner, E. Curti, and A. Thoenen, Nagra/PSI Chemical Thermodynamic Data Base, Nagra, Wettingen, Switzerland, 2008.

[33] K. J. Cantrell and R. H. Byrne, "Rare earth element complexation by carbonate and oxalate ions," Geochimica et Cosmochimica Acta, vol. 51, no. 3, pp. 597-605, 1987.

[34] J. H. Lee and R. H. Byrne, "Complexation of trivalent rare earth elements (Ce, Eu, Gd, Tb, Yb) by carbonate ions," Geochimica et Cosmochimica Acta, vol. 57, no. 2, pp. 295-302, 1993.

[35] Y. R. Luo and R. H. Byrne, "Carbonate complexation of yttrium and the rare earth elements in natural waters," Geochimica et Cosmochimica Acta, vol. 68, no. 4, pp. 691-699, 2004.

[36] Y. R. Luo and R. H. Byrne, "Carbonate complexation of yttrium and the rare earth elements in natural waters," Geochimica et Cosmochimica Acta, vol. 68, no. 4, pp. 691-699, 2004.

[37] M. E. Essington, Soil and Water Chemistry: An Integrative Approach, CRC, Boca Raton, Fla, USA, 2004.

[38] J. D. Allison, D. S. Brown, and K. L. Novo-Gradac, A Geochemical Assessment Model for Environmental Systems: Version 3.0, Environmental Research Laboratory, Office of Research and Development, U.S. Environmental Protection Agency, Athens, Ga, USA, 1999.

[39] C. M. Gramaccioli, V. Diella, and F. Demartin, "The role of fluoride complexes in REE geochemistry and the importance of $4 \mathrm{f}$ electrons: some examples in minerals," European Journal of Mineralogy, vol. 11, no. 6, pp. 983-992, 1999.

[40] J. F. Banfield and R. A. Eggleton, "Apatite replacement and rare earth mobilization, fractionation, and fixation during weathering," Clays \& Clay Minerals, vol. 37, no. 2, pp. 113-127, 1989.

[41] Z. S. Cetiner, S. A. Wood, and C. H. Gammons, "The aqueous geochemistry of the rare earth elements. Part XIV. The solubility of rare earth element phosphates from 23 to $150^{\circ} \mathrm{C}$," Chemical Geology, vol. 217, no. 1-2, pp. 147-169, 2005.

[42] S. Nagao, R. R. Rao, R. W. D. Killey, and J. L. Young, "Migration behavior of Eu(III) in sandy soil in the presence of dissolved organic materials," Radiochimica Acta, vol. 82, no. 1, pp. 205-211, 1998.

[43] O. Pourret, M. Davranche, G. Gruau, and A. Dia, "Competition between humic acid and carbonates for rare earth elements complexation," Journal of Colloid and Interface Science, vol. 305, no. 1, pp. 25-31, 2007.

[44] M. I. Prudêncio, M. A. S. Braga, and M. A. Gouveia, "REE mobilization, fractionation and precipitation during weathering of basalts," Chemical Geology, vol. 107, no. 3-4, pp. 251$254,1993$.

[45] J. J. Braun and M. Pagel, "Geochemical and mineralogical behavior of REE, Th and $\mathrm{U}$ in the Akongo lateritic profile (SW Cameroon)," Catena, vol. 21, no. 2-3, pp. 173-177, 1994.
[46] J. F. McCarthy, W. E. Sanford, and P. L. Stafford, "Lanthanide field tracers demonstrate enhanced transport of transuranic radionuclides by natural organic matter," Environmental Science and Technology, vol. 32, no. 24, pp. 3901-3906, 1998.

[47] M. Land, B. Öhlander, J. Ingri, and J. Thunberg, "Solid speciation and fractionation of rare earth elements in a spodosol profile from northern Sweden as revealed by sequential extraction," Chemical Geology, vol. 160, no. 1-2, pp. 121-138, 1999.

[48] P. Oliva, J. Viers, B. Dupré et al., "The effect of organic matter on chemical weathering: study of a small tropical watershed: Nsimi-Zoetele site, Cameroon," Geochimica et Cosmochimica Acta, vol. 63, no. 23-24, pp. 4013-4035, 1999.

[49] Z. Gu, X. Wang, X. Gu et al., "Determination of stability constants for rare earth elements and fulvic acids extracted from different soils," Talanta, vol. 53, no. 6, pp. 1163-1170, 2001.

[50] D. Wenming, W. Xiangke, B. Xiaoyan, W. Aixia, D. Jingzhou, and Z. Tao, "Comparative study on sorption/desorption of radioeuropium on alumina, bentonite and red earth: effects of $\mathrm{pH}$, ionic strength, fulvic acid, and iron oxides in red earth," Applied Radiation and Isotopes, vol. 54, no. 4, pp. 603-610, 2001.

[51] J. Schijf and R. H. Byrne, "Stability constants for mono-and dioxalato-complexes of $\mathrm{Y}$ and the REE, potentially important species in groundwaters and surface freshwaters," Geochimica et Cosmochimica Acta, vol. 65, no. 7, pp. 1037-1046, 2001.

[52] W. Zhenghua, L. Jun, G. Hongyan, W. Xiaorong, and Y. Chunsheng, "Adsorption isotherms of lanthanum to soil constituents and effects of $\mathrm{pH}$, EDTA and fulvic acid on adsorption of lanthanum onto goethite and humic acid," Chemical Speciation and Bioavailability, vol. 13, no. 3, pp. 75-81, 2001.

[53] D. Wenming, L. Weijuan, and T. Zuyi, "Use of the ion exchange method for the determination of stability constants of trivalent metal complexes with humic and fulvic acids II. $\mathrm{Tb}^{3+}$, $\mathrm{Yb}^{3+}$ and $\mathrm{Gd}^{3+}$ complexes in weakly alkaline conditions," $\mathrm{Ap}$ plied Radiation and Isotopes, vol. 56, no. 6, pp. 967-974, 2002.

[54] J. R. Lead, J. Hamilton-Taylor, A. Peters, S. Reiner, and E. Tipping, "Europium binding by fulvic acids," Analytica Chimica Acta, vol. 369, no. 1-2, pp. 171-180, 1998.

[55] G. Tyler and T. Olsson, "Conditions related to solubility of rare and minor elements in forest soils," Journal of Plant Nutrition and Soil Science, vol. 165, no. 5, pp. 594-601, 2002.

[56] B. Öhlander, M. Land, J. Ingri, and A. Widerlund, "Mobility of rare earth elements during weathering of till in northern Sweden," Applied Geochemistry, vol. 11, no. 1-2, pp. 93-99, 1996.

[57] X. Cao, Y. Chen, X. Wang, and X. Deng, "Effects of redox potential and $\mathrm{pH}$ value on the release of rare earth elements from soil," Chemosphere, vol. 44, no. 4, pp. 655-661, 2001.

[58] G. Tyler and T. Olsson, "Concentrations of 60 elements in the soil solution as related to the soil acidity," European Journal of Soil Science, vol. 52, no. 1, pp. 151-165, 2001.

[59] V. V. Nikonov, N. V. Lukina, and M. V. Frontas'eva, “Trace elements in Al-Fe-humus podzolic soils subjected to aerial pollution from the copper-nickel production industry in conditions of varying lithogenic background," Eurasian Soil Science, vol. 32, no. 3, pp. 338-349, 1999.

[60] B. Dupré, J. Viers, J. L. Dandurand et al., "Major and trace elements associated with colloids in organic-rich river waters: ultrafiltration of natural and spiked solutions," Chemical Geology, vol. 160, no. 1-2, pp. 63-80, 1999.

[61] G. Tyler and T. Olsson, "Plant uptake of major and minor mineral elements as influenced by soil acidity and liming," Plant and Soil, vol. 230, no. 2, pp. 307-321, 2001. 
[62] S. Zhang and X. Q. Shan, "Speciation of rare earth elements in soil and accumulation by wheat with rare earth fertilizer application," Environmental Pollution, vol. 112, no. 3, pp. 395405, 2001.

[63] F. Li, X. Shan, T. Zhang, and S. Zhang, "Evaluation of plant availability of rare earth elements in soils by chemical fractionation and multiple regression analysis," Environmental Pollution, vol. 102, no. 2-3, pp. 269-277, 1998.

[64] Y. Q. Wang, J. X. Sun, H. M. Chen, and F. Q. Guo, "Determination of the contents and distribution characteristics of REE in natural plants by NAA," Journal of Radioanalytical and Nuclear Chemistry, vol. 219, no. 1, pp. 99-103, 1997.

[65] M. T. Aide, T. Alexander, L. Heberlie et al., "Soil genesis on felsic rocks in the St. Francois Mountains. I. The role of saprolite and its influence on soil properties," Soil Science, vol. 164, no. 6, pp. 428-439, 1999.

[66] M. T. Aide, T. Michael, L. Heberlie, and P. Statler, "Soil genesis on felsic rocks in the St. Francois Mountains. II. The distribution of elements and their use in understanding weathering and elemental loss during genesis," Soil Science, vol. 164, no. 12, pp. 946-959, 1999.

[67] M. T. Aide and C. Smith-Aide, "Assessing soil genesis by rare-earth elemental analysis," Soil Science Society of America Journal, vol. 67, no. 5, pp. 1470-1476, 2003.

[68] I. Olmez, E. R. Sholkovitz, D. Hermann, and R. P. Eganhouse, "Rare earth elements in sediments off southern California: a new anthropogenic indicator," Environmental Science and Technology, vol. 25, no. 2, pp. 310-316, 1991.

[69] T. Berg, O. Royset, E. Steinnes, and M. Vadset, "Atmospheric trace element deposition: principal component analysis of ICP-MS data from moss samples," Environmental Pollution, vol. 88, no. 1, pp. 67-77, 1995.

[70] M. T. Aide, C. Aide, J. Dolde, and C. Guffey, "Geochemical indicators of external additions to soils in Big Bend National Park, Texas," Soil Science, vol. 168, no. 3, pp. 200-208, 2003.

[71] R. C. Price, C. M. Gray, R. E. Wilson, F. A. Frey, and S. R. Taylor, "The effects of weathering on rare-earth element, $\mathrm{Y}$ and $\mathrm{Ba}$ abundances in Tertiary basalts from southeastern Australia," Chemical Geology, vol. 93, no. 3-4, pp. 245-265, 1991.

[72] M. A. Gouveia, M. I. Prudêncio, M. O. Figueiredo et al., "Behavior of REE and other trace and major elements during weathering of granitic rocks, Évora, Portugal," Chemical Geology, vol. 107, no. 3-4, pp. 293-296, 1993.

[73] A. W. MacFarlane, A. Danielson, H. D. Holland, and S. B. Jacobsen, "REE chemistry and Sm-Nd systematics of late Archean weathering profiles in the Fortescue Group, Western Australia," Geochimica et Cosmochimica Acta, vol. 58, no. 7, pp. 1777-1794, 1994.

[74] L. Minařík, A. Žigová, J. Bendl, P. Skřivan, and M. Št’Astný, "The behaviour of rare-earth elements and Y during the rock weathering and soil formation in the Ricany granite massif, Central Bohemia," Science of the Total Environment, vol. 215, no. 1-2, pp. 101-111, 1998.

[75] B. Bauluz, M. J. Mayayo, C. Fernandez-Nieto, and J. M. G. Lopez, "Geochemistry of Precambrian and Paleozoic siliciclastic rocks from the Iberian Range (NE Spain): implications for source-area weathering, sorting, provenance, and tectonic setting," Chemical Geology, vol. 168, no. 1-2, pp. 135-150, 2000.

[76] B. Öhlander, J. Ingri, M. Land, and H. Schöberg, "Change of Sm-Nd isotope composition during weathering of till," Geochimica et Cosmochimica Acta, vol. 64, no. 5, pp. 813-820, 2000.
[77] D. J. Brown, P. A. Helmke, and M. K. Clayton, "Robust geochemical indices for redox and weathering on a granitic laterite landscape in Central Uganda," Geochimica et Cosmochimica Acta, vol. 67, no. 15, pp. 2711-2723, 2003.

[78] G. Tyler, "Vertical distribution of major, minor, and rare elements in a Haplic Podzol," Geoderma, vol. 119, no. 3-4, pp. 277-290, 2004.

[79] M. T. Aide, "Elemental composition of soil nodules from two Alfisols on an alluvial terrace in Missouri," Soil Science, vol. 170, no. 12, pp. 1022-1033, 2005.

[80] H. W. Nesbitt, "Mobility and fractionation of rare earth elements during weathering of a granodiorite," Nature, vol. 279, no. 5710, pp. 206-210, 1979.

[81] L. R. Duddy, "Redistribution and fractionation of rare-earth and other elements in a weathering profile," Chemical Geology, vol. 30, no. 4, pp. 363-381, 1980.

[82] M. T. Aide, Z. Pavich, M. E. Lilly, R. Thornton, and W. Kingery, "Plinthite formation in the coastal plain region of Mississippi," Soil Science, vol. 169, no. 9, pp. 613-623, 2004.

[83] M. T. Aide and C. C. Smith, "Soil genesis on peralkaline felsics in Big Bend National Park, Texas,” Soil Science, vol. 166, no. 3, pp. 209-221, 2001.

[84] M. T. Aide and Z. Pavich, "Rare earth element mobilization and migration in a Wisconsin spodosol," Soil Science, vol. 167, no. 10, pp. 680-691, 2002. 

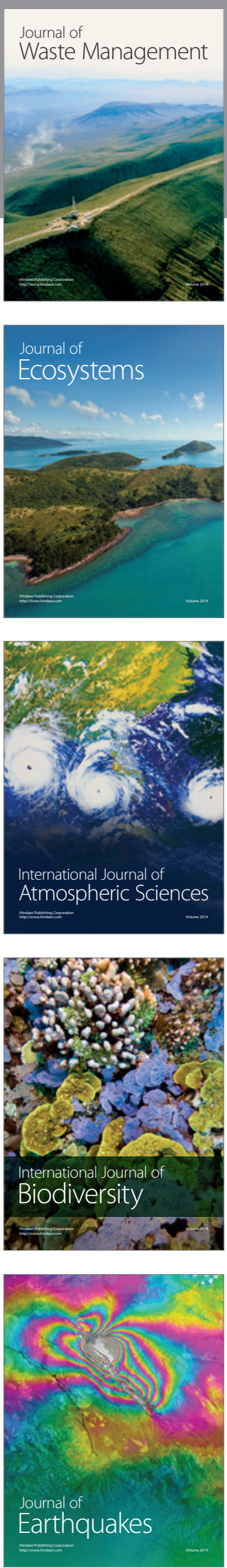
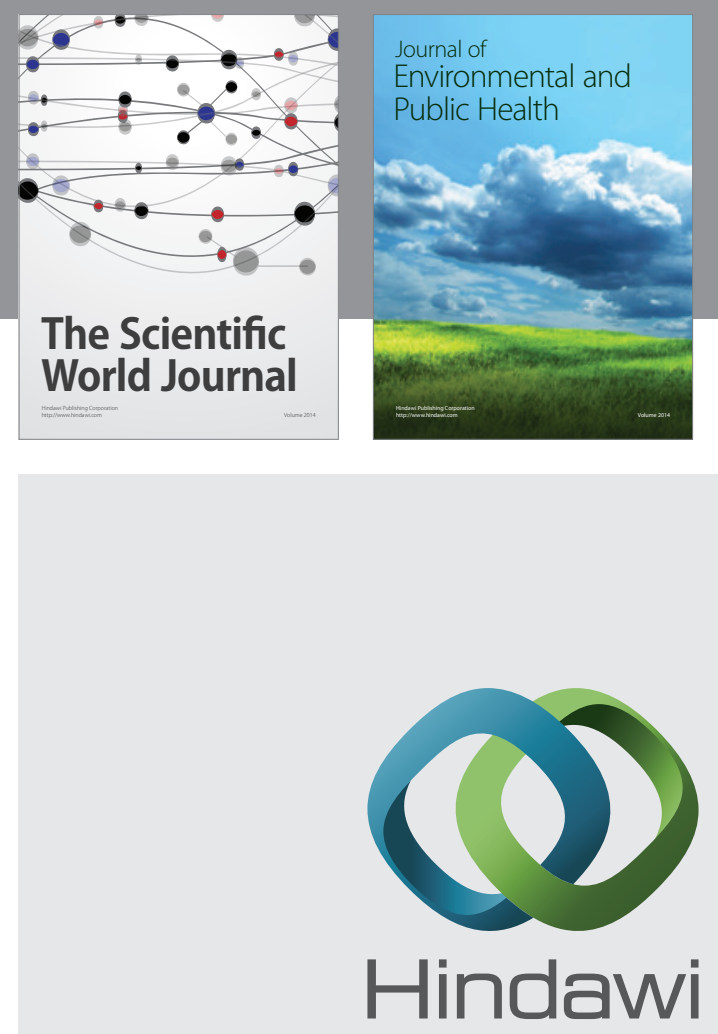

Submit your manuscripts at

http://www.hindawi.com
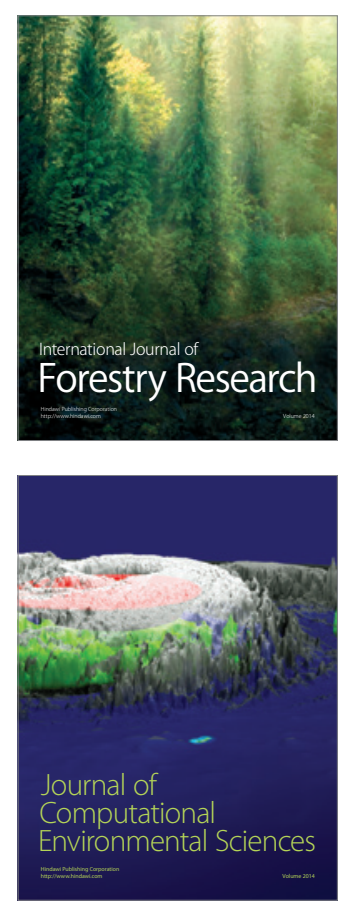
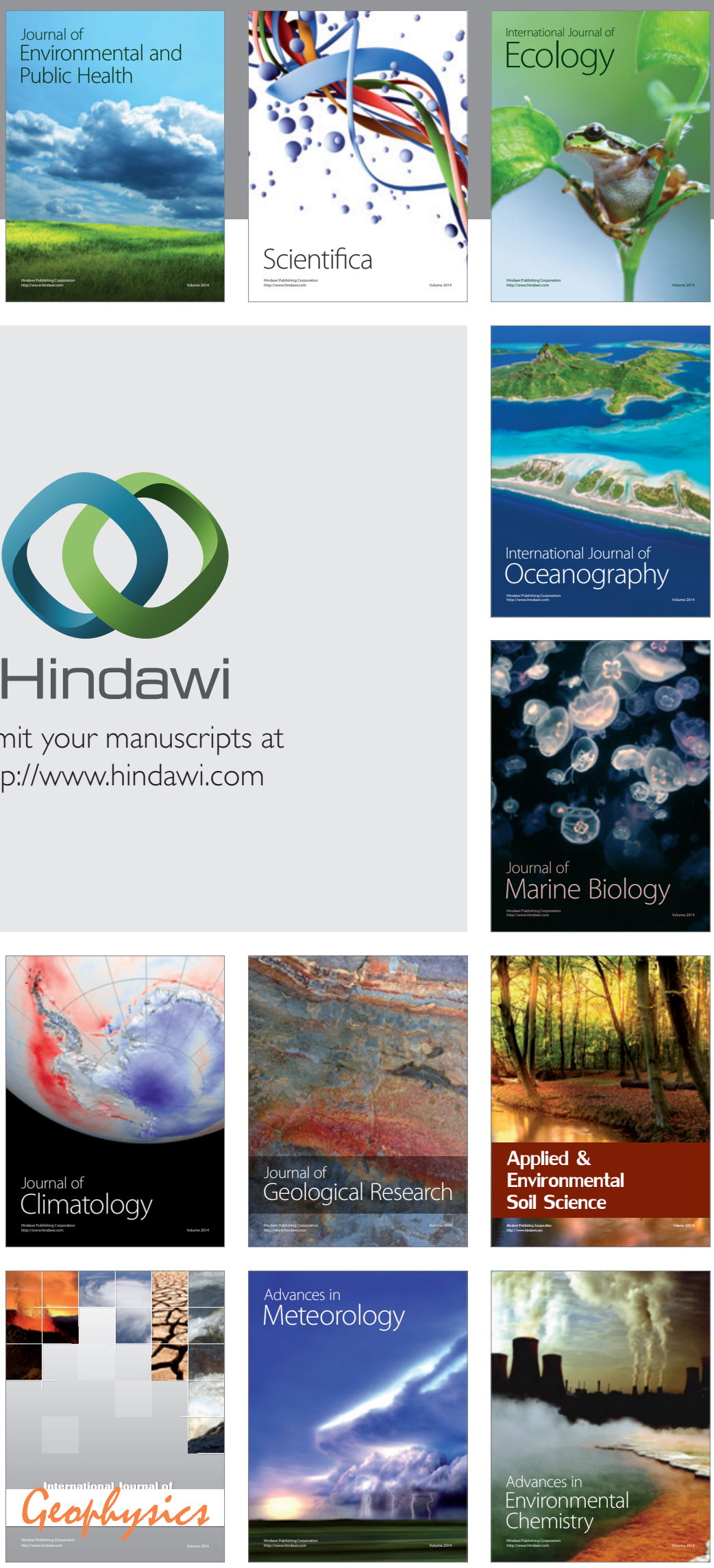